\title{
THE CONTEXTUAL CRITIQUE OF THE AESTHETICS OF FATIMID "WATER JUG COLANDER" AS AN INPUT TO ENRICH THE AESTHETIC EXPERIENCE OF ART EDUCATION'S STUDENTS
}

\author{
Jehan Farouk ABU AL-KHAIR*
}

Department of Art Education, Faculty of Specific Education, Alexandria University, Egypt

\begin{abstract}
Art represents the means of communication and effective communication between the artist and society, so artistic creativity is the ability to see and perceive and then respond and interact, and art has a special language that serves as a tool for the artist to communicate with others and interact with them. Art has become a means of communication that carries symbols, and translates the artist's emotions resulting from Conscience, experience, culture, thinking, and taste, and contribute to the transfer of experiences to the recipient in a correct manner. Art plays a role in the recipient's perception of his environment and the perception of its beauty. It reflects on the reader of the language of art, many cultural returns, such as visual and psychological enjoyment, assimilation of symbols, units and shapes, and an enrichment of his aesthetic experience. It is represented.

Keywords

The Contextual Critique, Aesthetics, Fatimid, Water Jug Colander, Enrich, The Aesthetic, Experience, Art Education.
\end{abstract}

\section{Introduction}

The problem facing the recipient in understanding the language of art and being influenced by its contents, for several reasons, most notably the lack of community understanding of this language, which is the final and direct result of the lack of artistic and visual culture among members of society.

The jug colander nets are the part that connects the neck of the oligarch with its body (pottery vessels for preserving drinking water, spread in the Islamic world) and its benefit is to regulate the flow of water when drinking, and to save water from impurities and insects.

The decoration of the window windows became a stand-alone art within the Islamic decorative arts and reached its peak in Egypt in the Fatimid era, where it became comparable to the art of openwork (lace cloth). Egyptian potters came to it from their creations many human drawings and drawings of animals, fish and birds, in addition to geometric shapes, especially in the Fatimid era. Fustat was one of the most famous Islamic cities, and its products from the windows of the pallets were an extension of the famous Egyptian pottery since the times of the pharaohs. This art also flourished in the Tulunid and Fatimid periods. And those traditions extended to the Egyptian regions, especially in Upper Egypt, and the Egyptian fashions, with their geometric window decorations, became famous in all Islamic countries. The manufacture of gill windows continued in the Ayyubid era and was characterized by its polygonal geometric

* Corresponding author: spedu@alexu.edu.eg 
shapes, such as triangles, rectangles, circles and stars, It is noticeable in that era the scarcity of decoration representing living organisms compared to the Fatimid period. In the Mamluk era, Cairo became Maha's center for the production of folk pottery, which was distinguished by its simplicity and low cost. She was the bug The most common species in Cairo and some cities in Upper Egypt, the most important of which is Qena. Potters have mastered throughout those aforementioned eras in creating many forms of window-filter decorations, which are decorations that indicate the ingenuity of pottery in the Islamic era and their superior skill, as well as testimony to good taste, imagination and the ability to innovate, as it proves that craftsmen in Islamic times used to innovate for art itself. In the Mamluk era, the potteries mastered the creation of many forms of reduction and the decoration of windows in a variety of styles. Names of famous people from the makers of small windows, such as: Qassem, Masri, Saad, Abed, and Youssef Al-Qallal, were common.

The studies of Shababeek Qalal did not get any less from the efforts of researchers in Islamic art in general, as it is an important part of the Islamic ceramic heritage. It prompts me here to review this phenomenon closely, by getting acquainted with the design foundations and construction systems upon which the decorations of the fry filters were based, and then extracting aesthetic values in order to enrich our information on that part of the Islamic ceramic heritage. And the study of the decorations of the windows of the pumice has not received sufficient attention from researchers until now. In that brief research on the windows of the faience, we had to shed light on the design elements of those windows, while studying the materials and manufacturing tools, and also getting acquainted with the aesthetic and functional aspects of them during the various Islamic periods of Fatimid, Ayyubid, Mamluk, Ottoman, and in Egypt in particular.

The present study used the principles of contextual criticism in dealing with the decorations of the window windows, which is the criticism that is concerned with environmental, social, historical and cultural factors of the artistic product. And we noted the ability of Islamic art to treat decorative spaces in an interesting diversity within a self-sufficient engineering space, thus highlighting the most important features of Islamic art, which is to benefit from all the elements that the artist's eye falls on in his environment, whether plant, animal or human, with mixing them with Arabic writing, Thus, the decorations of the windows of the kos that the Fustat excavations provided us with became a rich record of all the decorative elements that were common in the Islamic arts, within a tight engineering framework, and artistic criticism is one of the tools for tasting and understanding the various artworks in the field of arts, which is practiced by specialists to reach non-specialists to a full understanding and sense of the 
various flavors, values and aesthetics of artistic works. Art criticism is understood as appetite at its highest levels, and art criticism is considered a "methodological and objective science," based in its traditions and standards on modern sciences such as (psychology, aesthetics, logic, philosophy, ethics). Modern art criticism depends on the systematic analysis of artistic works, And successful criticism does not tend to praise, negligence, slander and satire, but rather places the artwork under a calm and examining light, away from enthusiasm, fanaticism or prejudice.

\section{Research background}

One of the direct results of the mixing of Islamic culture with other cultures of the nations that entered Islam, along with its arts, sciences and national heritage, of course, was that the Islamic culture was represented by many different cultures and civilizations, and it gave it an Islamic character that stems from the teachings of the true Islamic religion. The Islamic culture did not stop at the sciences translated by the Muslims only, but took those sciences as foundations and as a starting point for scientific thinking and experimentation based on induction and deduction. Among the Muslims, outstanding scholars also appeared in various fields of science.

The cultural friction between Muslim scholars and the translation movement has led to new innovations, including the areas from which the foundations of the geometric shapes were based, and which have become a feature of Islamic art, as the Muslim artist mastered the treatment of surfaces with geometric shapes compatible with the nature of the surface they occupy and the drawings were One of those applications is the decorative for the windows of the gills. The origin of art criticism is that it be an introduction to the appreciation and understanding of the aesthetic values in the artwork. Art criticism is an analytical process that enables the critical person to make people who are unable to taste works of art, to become able to perceive artistic and aesthetic values.

Through the practice of artistic criticism in the field of art education, the aesthetic experiences of students are refined so that they are able to taste beauty in the right ways, and their capabilities and critical thinking are developed to express the various aesthetic experiences that take place through viewing and drawing attention to learn about the values and aesthetic relationships and the development of perceptual perception. And developing the ability to use and practice artistic criticism, to express the aesthetic values and relations in artistic works and in the environment and nature through various theories and methods of criticism, from which the researcher selected the "Howard Resate" method for the purpose of enriching the aesthetic experience of students of the Faculty of Art Education. 


\section{Research Problem:}

Many analytical studies can be conducted with the aim of reaching the aesthetic values of the windows of negligence, through the use of contextual criticism methods, and from here the research problem crystallizes in the following question:

What is the possibility of benefiting from the rules of contextual criticism in revealing the aesthetic values of the windows of the oligarchs in the Fatimid era?

What is the possibility of enriching the aesthetic experience of art education students in practicing artistic criticism?

\section{Research hypotheses:}

1- Contextual criticism methods can be used to reveal the aesthetic values of some selections from the windows of the palace in the Fatimid era.

Aesthetic values can be derived by analyzing the decorations of the windowsills, using critical contextual methods.

\section{Research objectives}

1- Enriching the aesthetic experience of art education students through the use of contextual criticism to analyze the aesthetic values of the Fatimid palace windows.

2- Reaching a deeper understanding of Islamic art by using the methods of criticism and technical analysis (contextual criticism) for windows.

\section{Research importance}

The study of the decorations of the windows of the qilal throughout their historical eras in Egypt, from the perspective of contextual criticism, is of great importance to re-evaluate the Islamic ceramic heritage in general.

Study and clarify the important role that art criticism makes and its contributions to the field of art education.

- The development of the aesthetic experience, the critical and appetitive ability of the arts, the ability to distinguish aesthetic, in addition to the creative capabilities and cognitive experiences of the art education student teacher, through the diversity of artistic criticism methods used in understanding and tasting different works of art.

\section{Results and recommendations}

\section{A- Results:}

1- The ornaments and decorative units of the kale windows throughout the Islamic eras: Tulunid, Fatimid, Ayyubid and Mamluk, attracted the attention of researchers specializing in Islamic arts in particular, as they won the admiration of everyone who discovered them in the excavations of Fustat, and those art pieces proved beyond any doubt that the artist The Muslim 
loved art for its own sake and not for the purpose of utility and material as it was believed in those times, otherwise it would not have been made from that window, hiding in the hollow of the few out of sight, using digging and hollowing out in the pottery patch, a wonderful piece of lace fabric in this way..

2- The visual culture of the Muslim artist was formed, for the most part, from tributaries coming from the Byzantine (Eastern Roman), Persian, and Greek engineering arts, as they were mixed with the Arab-Islamic culture.

\section{B- Recommendations:}

1- The necessity of conducting more research and studies using the methodology and items of contextual criticism, in order to uncover all aspects of the achievements of Islamic art in general, and the decorations of the windows of the few in particular, in order to investigate the various tributaries of Islamic art and the various cultural environments that affected and are affected by them.

2. The necessity of diversifying critical studies using different critical doctrines to develop the abilities of a taste for Islamic arts among scholars and researchers.

3. We must pay attention to the symbolic dimensions and the philosophical visions behind the artwork, in order to reach a deeper understanding of the arts Islamic.

\section{References}

1. Ahmed Fikry, Cairo's Mosques and Schools, Dar Al Ma'arif, Cairo, 1965.

2. Tamadur Ibrahim, an article in Al-Thawra newspaper, entitled "Plastic criticism between a rock and a hard place", published by Al-Wehda Institution for Press, Printing and Publishing, Damascus, Syria, 2012.

3. Jerome Stollnitz, Art Criticism "An Aesthetic and Philosophical Study", translated by Fouad Zakaria, The Egyptian General Book Authority, Cairo, First Edition, 1981.

4. Hussein Mahmoud Ibrahim, Islamic Arts in the Fatimid Era, House of Arab Culture, Cairo, 2005 .

5. Rania Adel Hussein, Contextual Criticism and Its Benefit in the Aesthetic Interpretation of Symbolic Juana, Master Thesis, Faculty of Art Education, Helwan University, 2006

6. Richard Eiting Hosen, The Heritage of Islam (Decorative Arts and Photography, Its Character, and Its Scope), translated by: Hussein Mu'nis and Ihsan Al-Imam, The World of Knowledge, Part Two, Kuwait, National Council of Sciences, Arts and Literature, 1978 7. Zaki Muhammad Hassan, Atlas of Decorative Arts and Islamic Pictures, Al-Raed Al-Arabi House, Beirut: Lebanon, 1981.

7. Zaki Mohamed Hassan, Arts of Islam, Nahdet Misr Library, Cairo, 1948. 
8- Ziad Salem Haddad, Art Criticism (a collection of papers on nagat al-fannah translated from the English language with adaptation), first edition, Dar Al-Manahil for printing, publishing and distribution, Lebanon, 1993

9. Souad Maher, Islamic Arts, Egyptian General Book Authority, Cairo, 1986.

10. Sultan bin Hamad bin Muhammad Al-Shaheen, a proposed educational program in artistic appreciation and criticism based on interactive multimedia (and the extent to which it is used in the intermediate stage), an unpublished master's thesis, Department of Art Education, College of Education, Umm Al-Qura University, Kingdom of Saudi Arabia 2006.

11- Become El-Sharouny, Masterpieces of the Museum of Islamic Art in Cairo, the Egyptian Lebanese House, Cairo, 2008

12. Salah Fadl, Curricula for Contemporary Criticism, Atlas Publishing House, Cairo, 1996.

13. Tariq Bakr Qazzaz, The Nature of Contemporary Art Criticism in the Saudi Press, Unpublished Master Thesis, Department of Art Education, College of Education, Umm AlQura University, Kingdom of Saudi Arabia, 2002.

14. Tariq Bakr Qazzaz, Criticism and Appreciation of Plastic Arts ... Artistic Work, the Receptor and the Role of the Critic, Dialogue Forums, King Saud University, 2012.

15. Asim Muhammad Rizk, Arab and Islamic Arts in Egypt, Madbouly Library, Cairo, 2007.

16- Abdulaziz Alwan, The Notables of Art Criticism in History, the Syrian General Book Authority, the Syrian Ministry of Culture, First Edition, Damascus, 2011.

17. Afif Behansi, The Aesthetic of Arab Art, Talabi House for Studies, Translation and Publishing, Damascus, 1988.

22- Gio Guterchief, Consciousness and Art, translated by: Shaker Abdul Hamid, The World of Knowledge, No. 146, Kuwait, 1990.

18- A Group of Researchers, Art Criticism (a collection of research papers in art criticism translated from the English language with adaptation), compilation and translation / Ziad Salem Haddad, first edition, Dar Al-Manahil for Printing, Publishing and Distribution, Lebanon, 1993.

19- Mohsen Muhammad Attia, Trends in Modern and Contemporary Art, The Anglo-Egyptian Library, Cairo, 2011

20- Mohsen Mohamed Attia, New Horizons for Art, The World of Books, Cairo, 2002.

21. Mohsen Mohamed Attia, Aesthetic Analysis of Art, The World of Books, Cairo, 2003.

22 Mohsen Muhammad Attia, Criticism and Art Surprises, his study, Al-Muhit Al-Thaqafy Journal, Issue 23, September 2003.

23- Mohsen Mohamed Attia, Roots of Art, The Anglo-Egyptian Library, Cairo, 2004. 
24. Mohsen Mohamed Attia, Criticism of the Arts: From Classical to the Postmodern Era, Knowledge Institute, Alexandria, 2002.

25- Muhammad Abd al-Aziz Marzuq, Decorative Arts in the Pre-Fatimid Era, The AngloEgyptian Library, Cairo, 1974.

26- Mahmoud Ibrahim Hussein, Islamic Ceramics in Egypt, Nahdet Al Sharq Library, Cairo, 1984.

27- Mahmoud Ibrahim Hussein, Islamic Arts in the Fatimid Era, Gharib House for Printing, Publishing and Distribution, Cairo, 2010.

28- Mahmoud Al-Bassiouni, The Education of Aesthetic Taste, The Egyptian House of Knowledge, Cairo, 1986.

29- Nabil Ragheb, Art Criticism, Egypt Library, Cairo, 1996.

30- Nabil Muhammad Darwish, The Window of the Islamic Oligarchy, Research in Studies and Research on Islamic Civilization, 1972.

31. Hani Farouk Ibrahim, Islamic pallet windows as a source for enriching ceramic shapes, MA in Art Education (ceramics), Faculty of Art Education, Helwan University, 2000.

32. Bourgoin J. The decorative art of Arabia: Prisse D'Avennes. Yew York: Portland House; 1989.

33. Cromer J. History theory and practice of Art Education 'National Art

Education. USA: Reston Virginia; 1990.

35. Dobbes S. Learning in and through art. USA: The getty education institute for arts; 1998.

36. Durant W, Aried, The Story of Civilization. Vol. VIII, the age of Louis XIV, New York: Simon and Schuster; 1983.

37. Edmund Feldman, the teacher as model critic ،Journal of Aesthetic education7. No 1, January 1973.

38. Feldman E. The teacher as model critic. Journal of Aesthetic education

39. Inayat Muhammad Mahmoud KHALIL, PROFESSIONAL DEVELOPMENT FOR PREPARING A MUSIC EDUCATION TEACHER, International Journal of Education and Learning Research, Vol. 1, No. 2, 2018, pp. 17-20.

Received: February 2, 2019

Accepted: April 29, 2019 